\title{
Modern Technologies as Compensatory Means of Ensuring the Rights of Vulnerable Persons in Criminal Proceedings ${ }^{1}$
}

\author{
Svetlana M. Kurbatova, Larisa Yu. Aisner \\ Krasnoyarsk State Agrarian University, Krasnoyarsk, Russia
}

\begin{abstract}
This article presents theoretical and practical aspects of the use of modern technologies to promote the rights of persons with disabilities as participants in criminal proceedings. In this context, modern technologies are considered as means of compensatory nature. These technologies help persons with disabilities to become active participants in criminal procedural legal relations and independently exercise their rights and perform duties in the field of criminal proceedings. Through the use of modern technologies, persons with disabilities can level their position in relation to other participants in criminal proceedings who are active subjects of criminal procedural legal relations, and can independently exercise their rights and perform their duties. This is part of the compensatory approach that should be implemented in criminal proceedings in order to compensate persons with disabilities for the restrictions that they have due to circumstances beyond their control. The social vulnerability of individual members of society should be compensated by the state in the person of the legislator and further implemented by state bodies such as law enforcement officers. This is the essence of the compensatory approach. One can note the importance of this approach for observing human rights and building the rule of law and a welfare state in countries that view themselves as democratic. This is also important for improving the quality of international legal acts that introduce a standard for all States, members of the world community.
\end{abstract}

${ }^{1}$ In this article, the terms "vulnerable persons", "persons with disabilities", "socially vulnerable persons" will be used as equivalent. This is due to the fact that at the moment there is no single generally accepted terminology in the field that forms the subject of this study. At the same time, with a literal interpretation of the content of these terms, you can see their features, and a mismatch as a result. However, given the common essence that they have, in the context of the general topic of the article, the authors will use them as synonyms. 
In this connection, it is proposed to develop at the international level the direction of using the achievements of modern science and technology as means of compensatory nature, to equalize the legal status of persons with disabilities participating in criminal proceedings. As a general conclusion, a proposal is made to extend the compensatory approach not only to the field of criminal procedure, but also to the entire legal sphere, both in the norms of international law and national legislation.

Keywords: persons with disabilities; criminal proceedings; human rights; technologies; compensatory approach; compensatory means

Cite as: Kurbatova, S.M. and Aisner, L.Yu., (2021). Modern Technologies as Compensatory Means of Ensuring the Rights of Vulnerable Persons in Criminal Proceedings. Kutafin Law Review, 8(4), pp. 546-572, doi: 10.17803/2313-5395.2021.4.18.546-572.

\section{Contents}

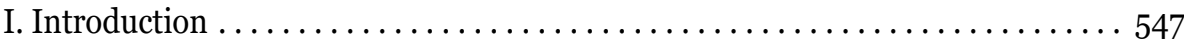

II. General Characteristics of the "Socially Vulnerable" Category of Persons. . . . . 548

III. Reflection of Humanistic Ideas of "Vulnerability" in the Norms of the Russian Criminal Procedure Law...................... 552

IV. The Possibilities of Modern Technologies to Ensure the Implementation of the Rights of Vulnerable Persons in Criminal Proceedings . . . . . . . . . 555

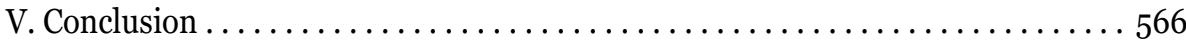

References......................................... 567

\section{Introduction}

Human rights have now become one of the fundamental institutions in connection with which international and national legal acts are formed, scientific schools are established, new, more diverse concepts and ideas are emerging to understand them, create conditions and provide opportunities for their implementation.

By the end of the twentieth century, the development of the world community and states reached such a humanistic level that one of the manifestations of this fact was the recognition that not all people, for various reasons, can independently exercise the rights granted to them. Age, illness, stress, physiological conditions, social factors and many 
other circumstances often become an insurmountable obstacle to this. As a result, human rights are violated. In some countries, because of this fact, a "barrier" is formed on the way to building the rule of law and a welfare state in them.

It becomes obvious that such a situation needs to be corrected, and such persons need to be provided with additional legal guarantees, means by which these subjects can exercise their rights and be full participants in various legal relations. This is the only way to ensure the observance of human rights for persons with disabilities.

Such situations, related to the difficulty of exercising their individual rights become particularly important when it comes to the scope of public law, for example, criminal proceedings. This state of affairs is characterized by the existence in this area of the imperative method of legal regulation and the public nature of legal relations, which can lead to the risk of human rights violations. If we speak about people who are not able to take care of themselves on their own, who are socially unprotected, vulnerable, then this becomes a difficulty to them.

There are different ways to solve this problem. This article will consider one of them, namely the use of modern technologies as a means of compensatory nature, with the help of which persons with disabilities can become active participants in criminal procedural legal relations and independently exercise their rights and perform their duties in the field of criminal proceedings.

\section{General Characteristics of the "Socially Vulnerable" Category of Persons}

Currently, there are various designations in the legal space that somehow reflect the characteristics of persons who, due to physical, mental, psychological, physiological, social and mixed reasons, need support and additional measures and means to equalize their position in comparison with other members of society. However, it is precisely because of the vagueness of understanding of who exactly belongs to this social group, as well as because of the well-established different approaches to this issue in different states, it is possible to note the variety of terms used. 
Thus, in various branches of law, in different spheres of Russian society and the state, you can find such terms as the "disabled," "vulnerable," "socially vulnerable," "cognitively vulnerable," "socially unprotected" as well as "a person who has found himself in a difficult life situation," "a person with disabilities," "a citizen with limited mobility," etc. (McCormic, 2004).

Examining the content of the definitions of several such concepts, A.M. Plotnikova draws attention to the fact that the "stable unit" a person with disabilities "is used as a hyperonym in relation to the hyponyms 'disabled person', 'wheelchair user', 'autistic person', 'deafblind person', etc. Interpretations offered by traditional explanatory dictionaries demonstrate the dominance of physiological features over social ones, and in ideographic dictionaries of the Russian language, the studied units are included in groups of nominations of persons by type of diseases" (Plotnikova, 2019, p. 209). At the end of her research, she concludes that "a number of issues concerning the use of certain units in the language of law, written business speech of charitable organizations and mass media discourse, as well as their reflection in the dictionaries of the modern Russian language" (Plotnikova, 2019, p. 209), thereby emphasizing the problem of the lack of uniformity in the legal understanding of terminology in this area. This creates a lack of a uniform approach on the part of the state in creating conditions for the full participation of persons from this category of the population in different spheres of life and providing them with opportunities to exercise their rights as participants in legal relations.

One of the options for solving this problem may be international law. The development of humanistic ideas, which began actively in the world since the middle of the twentieth century, as a result of the universal recognition of the importance of human rights that came after the end of the Second World War, is reflected in the content of international documents, and then in the norms of national legislation.

The formation of an understanding of the fact that the existing various socially unprotected groups of the population need to be united into a single general legal category in order to develop a unity of the 
conceptual apparatus, the foundations of their special legal status and legal guarantees for its implementation, has become one of the manifestations of this process.

Such a legal category is the term "vulnerable," which is already used at the UN level and is found in international legal acts. However, currently there is no international legal document that would interpret its concept, establish a list of criteria by which certain persons could be attributed to this category, etc. (Lewis, 2002). In the coming years (or even a decade), the adoption of such a legal document is not expected. Therefore, it is difficult to introduce any single terminology in this area at the level of national states: it is not known which basic term will be formulated and introduced as a result-"vulnerable," "socially vulnerable" or "vulnerability" will disappear from its content altogether.

In any case, according to S.E. Nesmeyanova and E.G. Kalinina, "states themselves should decide on the application of the concept of vulnerability and create a system for protecting the rights of vulnerable people that corresponds to national interests and international law" (Nesmeyanova and Kalinina, 2017, p. 7). We should agree with this, since today states, of course, should develop the ideas of the rule of law and a welfare state, improve them, and reflect them in the norms of their legislation. However, they need to be guided by the legal ideas and their semantic expressions and characteristics that have been formed in their legal environment, based on the provisions of international human rights instruments.

As for the grounds for assigning persons to this category, for example, according to V.G. Mikrina, they "are violations of human rights, lack of equality, discrimination based on gender differences, on physiological characteristics, age and legal status of a person" (Mikrina, 2019, p. 12). She highlights the fact that "two factors are involved in the formation of vulnerable groups of the population: external and internal. The external influence on the degree of legal insecurity is exerted by the world community itself, which accumulates unfavorable conditions for a certain category of persons. In turn, internal individual physical or mental characteristics, age, gender, disability, any vulnerability in the legal situation lead to risks 
of becoming a victim of violations of fundamental human rights and freedoms" (Mikrina, 2019, p. 13).

E.S. Alisievich also believes that "the vulnerability of an individual or a group of the population means, first of all, a higher risk than others due to objective external factors and (or) existing physical or psychological characteristics of becoming a victim of violations of human rights and freedoms, including being limited in the ability to realize the rights and freedoms guaranteed to everyone" (Alisievich, 2012, p. 14).

Adhering to this line of reasoning, as well as taking into account a number of the following factors:

1) the term "a disabled person" currently used in the Russian legislation (and as a result - in society) does not correspond to the spirit and letter of modern international law, ${ }^{2}$

2) there is already a fundamental international act defining the basis for the special status of persons with disabilities - the UN Convention on the Rights of Persons with Disabilities of 2006 (hereinafter also the Convention),

3) the purpose of the Convention is "to promote, protect and ensure the full and equal enjoyment by persons with disabilities of all human rights and fundamental freedoms" (article 2 of the Convention),

4) a number of articles of the Convention aimed at creating conditions for the possibility of participation of vulnerable persons in court proceedings, including in criminal cases, ${ }^{3}$

we can suggest the term "persons with disabilities" should be used in the Russian legislation for the regulation of the rights and interests of this category of the population (including in the field of criminal proceedings).

${ }^{2}$ Literally translated, "disabled" means "defective", which is degrading to the human dignity of people belonging to this category. It was on this basis that the UN Convention on the Rights of Persons with Disabilities of 2006 was adopted, which made a departure from the previously existing medical approach to identifying such a category of the population. Now it "includes persons with persistent physical, mental, intellectual or sensory impairments that, when interacting with various barriers, may interfere with their full and effective participation in society on an equal basis with others" (Article 2 of the Convention).

3 For example, Article 12 "Equality of all before the law", Article 13 "Access to justice", Article 14 "Freedom and personal integrity", etc. 


\section{Reflection of Humanistic Ideas of "Vulnerability" in the Norms of the Russian Criminal Procedure Law}

The formation of an enlarged legal category from among persons who, due to external or internal factors, need some external support in order to be full-fledged members of society and enjoy the rights of a citizen of the Russian Federation is a natural process of evolution of the Russian state (Nagornaya, 2021). In some areas, this has been more developed, in some - less (Sinkovskaya et al., 2020). The first ones include the system of social protection of the population, education, the field of providing medical care and providing medical services, labor relations, etc. The second category includes, in particular, the sphere of criminal proceedings, the main source of law for which is the Criminal Procedure Code of the Russian Federation (hereinafter also referred to as the Code of Criminal Procedure of the Russian Federation), adopted in 2001.

The basis of this normative legal act is the accumulated historical experience of our state in the field of legal regulation of criminal procedural relations. Indeed, if we analyze the history of the formation and development of the Russian criminal procedure legislation, we can see how gradually, sometimes slowly, sometimes more intensively, changes in the Russian criminal procedure took place, increasingly reflecting humanistic ideas concerning the understanding of the characteristics of certain participants in criminal procedure relations from among the so-called "vulnerable" persons (Kurbatova, 2021b, pp. 146-147).

Despite the ongoing humanization of the criminal policy in our state, the Criminal Procedure Code of the Russian Federation does not differ much in this regard from the previous Criminal Procedure Code - the Criminal Procedure Code of the RSFSR of 1960. First, the categories of persons that are distinguished by the modern legislator as holders of a special procedural status in fact have remained unchanged, these are minors and persons in respect of whom proceedings are being carried out on the application of compulsory medical measures. But even despite the existence of such independent chapters as "Proceedings 
on criminal cases against minors" (Chapter 50) and "Proceedings on the use of compulsory medical measures" (Chapter 51), scholars and practitioners have accumulated quite a number of questions about their content (Bertovsky, 2021, pp. 9-15; Vorotnikova, Gavrilov, Drobysheva, et al. in Chernov, 2010, pp. 95-100; Kachalova, 2019, p. 11; Nikolyuk, Kalnitsky, 1990; Shatalov, 2014 , pp. 41-45 and others) although there are relevant explanations at the level of the Plenum of the Supreme Court of the Russian Federation. ${ }^{4}$ Second, at the same time, the Criminal Procedure Code of the Russian Federation has not established the institution of procedural legal capacity and legal capacity, although the need for such an approach was repeatedly raised by Soviet scholarsin the second half of the twentieth century (L.D. Kokorev, I.L. Petukhov, P.V. Poloskov, V.M. Savitsky, M.S. Strogovich, etc.).

The category of legal capacity can and should be the basis for the legal regulation of the procedural status of participants in criminal proceedings. First, it is characteristic of the theory of Russian law and familiar to it. Second, it has shown its effectiveness in civil branches, where it has been successfully used for a long period. Third, it would reflect a unified approach to the legal regulation of basic categories, which should be initially uniform in their legal understanding and only then be disclosed taking into account the specifics of a particular branch of law.

Fourth, when it comes to persons with disabilities as participants in legal relations, based on the essence of the institution of legal capacity, they can be classified as holders of "limited legal capacity" or even "incapacitated" with all the legal consequences resulting from this, due to the specifics of a particular branch of law.

With regard to criminal proceedings, it is necessary differentiate its participants who have limited legal capacity due to the reason and nature of their limited capabilities, as a result of which they cannot

${ }_{4}$ Plenum of the Supreme Court of the Russian Federation. On the judicial practice of applying legislation regulating the peculiarities of criminal liability and punishment of minors (with amendments and additions) Resolution (2011), in Legal reference system "ConsultantPlus"; etc. 
fully independently exercise their procedural rights, perform duties, and protect their interests:

1) with physical disabilities (limited opportunities are the result of illness, injuries, making it difficult or impossible to have real access to justice in one or another of its manifestation) (Kurbatova et al., 2020);

2) with cognitive disabilities (limited abilities reflect the result of the age-related development of minors, as well as reverse age-related processes in old age, existing mental diseases, psychological disorders, physiological conditions, social factors) (Kurbatova, 2019, p. 134);

3) with physical and cognitive disabilities combined.

If we speak about the first group of restrictions, then we should consider the possibility of leveling them by providing technical means: the use of video conferencing to obtain indications from people with limited mobility, the provision of special devices for blind and visually impaired participants, sign language-for the deaf and hard of hearing, etc. (Schmetzke, 2002, pp. 135-136).

In cases where a participant in criminal proceedings has cognitive impairments, evidenced by medical documentation, or gives reason to believe his behavior, as well as age or there is a petition received from himself or from his legal representatives or relatives, this should entail the appointment and conduct of a forensic psychiatric or forensic psychological examination in order to determine the level of his cognitive abilities and the possibility of being a participant in criminal procedural relations (Gudjonsson et al., 2000, pp. 307-314).

In the third case, when there are restrictions caused by both physical and other reasons (for example, prolonged depression due to the amputation of the limbs), it is necessary to use combined means.

These general criteria should be fixed in relation to all participants in criminal procedural legal relations, regardless of their legal status.

The peculiarities of the procedural status of the participant should also be taken into account, but this should be secondary to the basic concept of the procedural capacity of all participants in criminal proceedings. 


\section{The Possibilities of Modern Technologies to Ensure the Implementation of the Rights of Vulnerable Persons in Criminal Proceedings}

The analysis of the world history and the development of humanistic ideas allows us to identify the following three stages in the formation and development of the attitude of the authorities to persons with disabilities.

1) Before the 20th century, when the disabled and the sick were perceived as "non-members of society," they were isolated (especially with infectious diseases), and society itself tried to isolate itself from such people, since the infrastructure and social structure of those eras did not allow people with disabilities to be part of that world, to participate in its life;

2) The 2oth century, when, on the one hand, there was an increase in the number of disabled people as a result of wars that became more frequent in a number and scale, on the other hand, the development of sciences took place, including medical and humanistic ideas.

All these factors contributed to a change in the attitude towards these people in society and, as a result, at the level of states and the international community, since the First World War, the institution of rehabilitation has become a policy direction of many states, since "the governments of many countries have faced the need to qualitatively change the existing system of medical and social assistance in order to return disabled people to life and active activity. Temporarily incapacitated sick people of a young and older age, due to the powerful biological potential inherent in them, sought a full-fledged life, and not living out in hospitals and shelters" (Puzin et al., 2017, p. 126);

3) The 21st century, when, along with the medical criterion, social and philosophical criteria (Barinova, 2015, p. 9) are fixed at the international level, and states are tasked with creating conditions for ensuring that persons with disabilities actively participate as members of society, including the implementation of their rights and legitimate interests as participants in legal relations.

For these purposes, the achievements of science and technology become more and more in demand, and modern technologies (Kbar 
et al., 2017, pp. 3-20) and innovations largely make up for those missing or impaired functions in people with disabilities (Maksimenko et al., 2016, pp. 166-175).

However, in Russia, until recent years, the emphasis was on medical rehabilitation (Ivanova, 2016, p. 9), aimed at compensating for lost (affected) body functions and maintaining them. ${ }^{5}$ Now, especially after adopting the UN Convention on the Rights of Persons with Disabilities by the Russian Federation in 2012, social rehabilitation has been developed. It focuses on creating a "barrier-free and accessible environment," where a special role is assigned to technical means and technologies, ${ }^{6}$ and although there is, in general, a positive trend in providing people with disabilities with technical means (Ryazantsev et al., 2020, pp. 2728), nevertheless, this is not enough in these two areas of social policy in relation to this category of persons (Andreeva and Bochkova, 2020, p. 82), not to mention their development, spreading to all major areas.

In particular, we are referring to the sphere of criminal proceedings. Thus, the Russian criminal procedure legislation does not contain the norms defining the conditions for the implementation of their rights as participants in criminal procedural legal relations by persons with disabilities participating in criminal proceedings.

Modern Russian criminal procedure legislation, in addition to minors and persons in respect of whom proceedings on the use of compulsory medical measures are carried out, does not contain any systematic allocation of a category of the population officially recognized by the state as "having limited opportunities," and as

${ }^{5}$ Federal Law of the Russian Federation No 323-FZ (November 21, 2011). On the basics of public health protection in the Russian Federation [Electronic resource]; Order of the Ministry of Health and Social Development of the Russian Federation No 1183 (December 20, 2012). On approval of the nomenclature of positions of medical and pharmaceutical workers [Electronic resource]; The State Program of the Russian Federation (adopted by the Board of the Ministry of Health of the Russian Federation on September 28, 2012). Development of Healthcare, etc.

${ }^{6}$ Decree of the Government of the Russian Federation No 2347-r (December 30, 2005). On the federal list of rehabilitation measures, technical means of rehabilitation and services provided to a disabled person [Electronic resource]; Decree of the Government of the Russian Federation No 1297 (December 1, 2015). On approval of the state program of the Russian Federation "Accessible Environment" for 20112020 [Electronic resource], etc. 
a result, needing state support measures to ensure the implementation of the rights of participants in criminal proceedings. Accordingly, the issue of removing with the help of modern technologies the restrictions that create limited opportunities for the people with disabilities remains unresolved.

Analyzing the statistics of persons recognized as disabled in Russia (i.e., the medical indicator is taken as the basis in this case), Professor A.S. Shatalov notes (Shatalov, 2021, pp. 203-204) that currently the largest groups among them are represented by the following persons:

- wheelchair users (about 350 thousand people);

- having complete or partial loss of visual function (approximately 11 thousand out of 100 thousand people suffer from blindness);

- there are about 300 thousand citizens in the Russian Federation who are totally deaf, and more than 13 million people with hearing problems. In reality, there are many more, and the a vast majority in this group are elderly people who have diseases that lead to gradual hearing loss (including autoimmune diseases, tumors, injuries, infections of the middle and inner ear, diabetes, etc.). So, as of October 1, 2020, the number of pensioners in Russia receiving an old-age insurance pension was 36.1 million. $^{7}$

At the same time, it should be taken into account that the number of these people is higher - not all of them, as a result of objective and subjective reasons, begin to formalize their social status and (or) reach the end in this bureaucratic process and thereby are included in official statistics.

In addition, a huge number of diseases that limit human mobility are recorded in Russia (including traumatic brain injuries, strokes, paralysis of various types, motor disorders, pathological vascular atherosclerosis, partial muscular atrophy, etc.), their number may well reach one million people, and even more people suffering from various mental disorders: for example, at the XVII Congress of Psychiatrists of Russia held in May 2021, the figure of 5-6 million people was announced. ${ }^{8}$

7 Federal State Statistics Service. Available at: https://rosstat.gov.ru [Accessed 24.07.2021].

${ }^{8}$ Ivanov, A. The number of Russians with mental disorders is named. Available at: https://36otv.ru/news/zdorove/nazvano-chislo-rossijan-s-psihicheskimirasstrojstvami/?utm_referrer=https\%253A\% 252F\%252Fyandex.ru\% $252 \mathrm{~F} \%$ 253Ffrom\%253Dalice [Accessed 24.07.2021]. 
However, physiological and other conditions that do not belong to medical criteria in Russia remain outside the statistics, which means that people live under such conditions do not receive the legal and other protection that they could count on under the UN Convention on the Rights of Persons with Disabilities.

Accordingly, the involvement of these persons in the sphere of criminal proceedings as suspects, accused, victims, witnesses ${ }^{9}$ a priori creates a situation where they cannot exercise their rights at all or in full. However, in some cases, modern technologies could be used to help such people.

The essence of criminal proceedings is the process of proof: the collection, verification and evaluation of evidence, which is, information that is relevant to the case and meets the requirements established by law. As a rule, participants in criminal proceedings from among persons with disabilities do not have free access to information, or rather, to the processes for receiving and transmitting it, which is caused by their limited abilities to see, hear, touch, and speak.

However, in ordinary life, the so called "assistive" (auxiliary) technologies are used to overcome such barriers - "devices, products, equipment, software or services aimed at strengthening, supporting or improving the functional capabilities of people with disabilities" (Karpov, 2013, pp.114-115). Let us focus on their general characteristics before turning to the analysis of the use of their capabilities in criminal proceedings.

Assistive technologies are mechanical, electronic, software and other technologies that can be classified according to their purpose (Dokhoyan and Maslova, 2020, p. 39):

1) "technologies for persons with disabilities of sensory functions:

- for persons with hearing impairments (surdo-informational means);

- for people with visual impairments (Al-Jaleeli, 2019, pp. 72-77);

- for persons with speech disorders (voice-forming means);

9 Although we can talk about other participants, nevertheless, it is enough to limit ourselves to the main ones listed in the text of the article to show the significance of the current situation. 
2) technologies for people with disabilities of the musculoskeletal system (motor disorders) (Poveda Zavala et al., 2019, pp. 35-47);

3) for people with limited cognitive abilities (mental, developmental disorders) (Shabalina et al., 2018, pp. 565-573);

4) technologies for people with general medical restrictions (for example, for the elderly or people with serious illnesses) (Jones et al., 2020, p. 381).

For example, today such assistive means are widely used for the rehabilitation of persons with visual impairments, such as: a speech text scanner with speech output, screen magnifiers (magnifiers), screen reading programs, voice calculators, a speech synthesizer for Braille displays and printers, computers for the blind, etc." For people with hearing disorders, these are hearing aids, cochlear implants, etc.; for people with musculoskeletal disorders-virtual keyboards, mice for computers controlled by feet ("Foot Mouse") "manipulators-mice," devices for turning books, tracking the head, eye direction, etc.

Today's modern technologies use the achievements of science and technology, called the "fourth industrial revolution," that are based on the automation and digitalization of technical processes under the control of intelligence systems that strive for globalization and a largescale space of action (Marzec and Stefaniak, 2017, pp. 463-470). It came at the beginning of the 21st century, replacing the "third industrial revolution" that had occurred in the second half of the 2oth century, which gave the world automation and robotics.

For people with disabilities, the third revolution contributed to solving many problems related to the accessibility of the environment, with the possibility of self-service there appeared robotic prosthetics of lost limbs, automated wheelchairs, equipment for physiotherapy and sports, mechanisms for movement, orthopedic products were actively developed, etc.

However, thanks to the fourth industrial revolution, the lives of people with disabilities began to change for the better even more significantly. Largely due to the computer gaming industry (Sedykh, 2020, p. 11), which was of interest for investment (Brezhneva, 2017, 
p. 129), and thus reached a new level, the technologies were also used to support people with disabilities. This was also facilitated by the general development of network and virtual technologies (Polutin et al., 2005, p. 97).

Taking into account the purpose, objectives and essence of criminal proceedings (Davletov and Azarenok, 2013, p. 124), criminal procedural evidence (Litvinova, 2011, p. 201) the institution of participants in criminal proceedings (Zelenina, 2010, p. 238), in order to ensure equality of citizens before the law and the court, it is possible and necessary to use traditional and modern technologies to promote the proper participation of persons with disabilities in criminal proceedings.

This use of technologies should be aimed at reaching the following tasks:

- providing people with disabilities with information in a clear and accessible form;

- using of various means and forms of communication with them;

- ensuring their physical access to justice at all stages of the process.

In order to facilitate the proper participation of persons with disabilities in criminal proceedings, in particular, modern technologies can be used in the following mode (Kurbatova, 2021a, p. 106).

- Automation of all programs for blind people should be reached. For example, Duxbury Systems have been doing it since the 1970s and they have become the world leader of this software production today. Its most famous product is the Duxbury Braille Translator (DBT) program. It is now used all over the world to prepare for printing any documentation in Braille. The principle of operation is based on bidirectional translation: a regular font is translated into Braille and back. With DBT, you can prepare any document for printing in Braille in many languages, in various encodings. ${ }^{10}$

- Fixing in the Russian Code of Criminal Procedure the possibility to produce protocols of procedural actions in which blind and visually impaired persons participated with the use of such programs, as well as printing out protocols using Braille would largely solve the problem

${ }_{10}$ Duxbury Braille Translator. Available at: https://elitagroup.ru/pages/prodDBT [Accessed 25.07.2021]. 
of participation of persons with disabilities and would facilitate their right to directly familiarize themselves with the materials of the criminal case and other relevant to the process (Kurbatova, 2020, pp. 236-241).

- Technologies that can be used to convert human brain signals into digital signals, would allow to create a symbiotic relationship between a person and a machine. ${ }^{11}$ These technologies help people with difficult functions of self-expression to control and manage electronic devices, providing themselves, among other things, a communication environment, ${ }^{12}$ send text messages, use the capabilities of the Internet and not only with the help of a brain interface (Oxley et al., 2020, p. 102). These technologies are aimed at ensuring that participants in criminal proceedings from among persons with disabilities exercise the right to appeal, to petition and appeal, to give evidence, etc.

- An algorithm for the early diagnosis of Alzheimer's disease, operating on artificial intelligence, can be elaborated. The use of this diagnosis is especially relevant when the participants in criminal procedural relations are persons of older age groups who, due to their age, belong to the category of people most vulnerable to this disease. For example, the algorithm presented by scientists in 2020 in the Journal of Medical Imaging (Parmar et al., 2020, p. 11).

- Technologies aimed at eliminating chronic and severe pain, for example, in the extremities, postoperative pain and chronic migraines, etc., can be introduced. The use of such technologies is of particular importance when, for example, it is very important to get the necessary information from an eyewitness whose health was seriously affected as a result of the crime committed for an investigation "in hot pursuit." 13

- "Memory prostheses" are being actively developed and, apparently, in the near future, "memory prostheses" will appear in circulationexternal devices with the help of which it is possible to load human memory into a computer and then transfer information directly to the hippocampus. ${ }^{14}$ For example, this is the endovascular neural interface

${ }^{11}$ Neuralink. Available at: https://neuralink.com/ [Accessed 25.07.2021].

${ }_{12}$ CTRL-labs. Available at: https://www.ctrl-labs.com/ [Accessed 25.07.2021].

${ }_{13}$ Neuros Medical. Available at: https://www.neurosmedical.com/ [Accessed 25.07.2021].

14 A New Era for Neuroscience. Available at: https://www.kernel.com/ [Accessed 25.07.2021]. 
Stentrode, whose task is to provide paralyzed patients with a safe way to put their brain under their control, which in the future will allow, by connecting the brain to a computer, to receive and convert incoming signals into words. ${ }^{15}$ Interfaces for controlling a computer using brain activity are developed by Neurable. ${ }^{16}$

- One should introduce technologies aimed at helping people with disabilities to better navigate and interact with the world around them, for example, the blind, those with amputated limbs, spinal cord injuries, etc. ${ }^{17}$

- Scientific developments, applications using artificial intelligence and augmented reality that facilitate the interaction of people with speech pathologies should be implemented. ${ }^{18}$ For example, computerbased communicators and their derivatives are already widespread, where a text is created on the screen using the SpeechPro software tool, which appears thanks to the suggestions offered by the program, based on the general meaning of its content. These can be the endings of the entered words or phrases that fit the context. As a result, the interlocutor can be presented with the typed text, but also, due to the existing synthesizer, it can be voiced by the program. ${ }^{19}$

Another successfully used software tool - Web TrekConnect, designed for sending emails and messages, is based on an approach where the user does not need the ability to read and write. The program has technologies for automatically generating recording and sending audio messages, which is facilitated by a simple interface, as well as voicing the text of incoming messages..$^{20}$ The developed Dragon Naturally Speaking program can translate oral speech into written text with an accuracy of up to $99 \%$ and vice versa. ${ }^{21}$

${ }^{15}$ Synchron Neurovascular Bioelectronics. Available at: https://www. synchronmed.com/ [Accessed 25.07.2021].

${ }_{16}$ Neurable. Available at: https://neurable.com/ [Accessed 25.07.2021].

17 Paradromics - The new generation brain computer interface. Available at: https://paradromics.com/ [Accessed 25.07.2021].

${ }_{18}$ Cognixion. Available at: https://www.cognixion.com [Accessed 25.07.2021].

19 Attainment Company, Inc. Available at: https://www.attainmentcompany.com [Accessed 25.07.2021].

${ }^{20}$ Attainment Company, Inc. Available at: https://www.attainmentcompany. com [Accessed 25.07.2021].

${ }^{21}$ Cognitive Aids - BrainAid. Available at: http://brainaid.com/index.html [Accessed 25.07.2021]. 
- The Reading PenBasic technology, implemented in the form of a large felt-tip pen, has a screen and a sound speaker built in. If such a pen is drawn over a readable word, it appears in large block letters on the screen of the "pen," and at the same time it is voiced through the built-in speaker. If necessary, by pressing the key on the "felt-tip pen," the word on the screen will be divided into syllables and also will be voiced by the speaker. There is a key, by clicking on which you can get the meaning of the word, which will also be played by the speaker. The vocabulary capabilities of this technology are still quite limited and they are more focused on meeting the general communication needs of such persons. However, their development and further use in criminal proceedings would contribute to the realization of human rights for participants using the "reading pen," both to obtain information and to clarify and interpret incomprehensible legal and other terms and words.

- Touch screens help to establish a contact and receive information from persons with limited cognitive abilities, which can also be successfully used for the purposes of criminal proceedings by the subjects conducting the proceedings.

Here are just a few groups of technologies aimed at helping people with disabilities involved in criminal proceedings. They could be used in Russian criminal proceedings, but in fact they are not. There are a number of reasons for this:

- not all of these and similar technologies aimed at helping people with disabilities are widely available;

- this affects their price plays a role: often the cost is quite high and on a large scale their acquisition and use will put a financial burden on their customer, in this case it will be assigned to the state budget;

- currently, there are various problems related to criminal proceedings and technologies in general: its digitalization (Voskobitova, 2019, p. 75), the use of block chain systems (Bertovsky and Devyatkin, 2019, p. 116) and information technologies (Shatalov, 2020, p. 239), etc.;

- one of the reasons, according to S.M. Kurbatova, is the question "about their admissibility from the point of view of criminal procedure legislation. Accordingly, it is necessary to provide for norms regulating 
the use of such funds in criminal proceedings. After all, it should be understood that they can provide compensatory assistance to persons with disabilities, but they can also carry certain risks in the event of their malicious use: with their help, it will be possible to influence decision-making or to pass off the result they received as the will of the person against whom they were used. For example, if a paralyzed person gives evidence, while moving the computer mouse with the power of thought or forming thoughts directly into the gadget interface, then there must be a guarantee that this person is doing it, and not, for example, an investigator, an inquirer, a prosecutor, a case officer, etc." (Kurbatova, 2021a, p. 109);

- appropriate specialists are needed who would have the skills to work with these technologies.

The need for proper training and regular retraining of employees is now generally recognized in all spheres of labor activity. This determines the importance of a close connection between the labor market and the education system. Especially in recent decades, when constantly changing information and other technologies require employees to have more and more knowledge in this field. Taking into account the fact that modern technologies increase the guarantees of the possibility of protecting personal rights, then, according to the authors, the development of such educational products that are aimed at ensuring this through appropriate training of personnel is of well-deserved interest.

In the context of the problem considered in this article, we speak about the need to form appropriate competencies for law enforcement officers who implement the function of criminal prosecution and related to it.

Professor L.V. Bertovsky believes that modern law has such a criterion as "logistics," which means that "the norms regulating the use of modern technologies have found their place in almost all modern branches of law. Modern law, on the one hand, being aimed at regulating new relations in increasingly large spheres of life of modern society, where high technologies are the objects (and in some cases already subjects), on the other hand, law itself uses high technologies as a form, 
means (and sometimes subject) of its creation and implementation, being logistical, knowledge-intensive and technological” (Bertovsky, 2021, p. 47).

First of all, these are officials of the authorities representing the prosecution - the preliminary investigation bodies (investigators and interrogators), prosecutors. They are the main subjects for collecting, verifying and evaluating evidence, and their understanding of the characteristics of persons with disabilities is of particular importance. The same applies to the court, as a body that administers justice.

It is also necessary to try to involve lawyers and other representatives of participants in criminal proceedings who have the appropriate knowledge and skills to interact with persons with disabilities in such criminal cases. The same is important for officials associated with the implementation of criminal proceedings - operational officers, employees of the penal enforcement system, etc.

To do this, it is necessary, first of all, to pay attention to the education system as a whole and to provide additional competencies in the educational programs of higher and secondary vocational education. We speak about both digital content competencies and competencies focused on obtaining more knowledge about people with disabilities as possible participants in legal relations in which a future employee will find himself in the process of implementing his work functions. With regard to "digital competencies," a positive result is already visible. For example, on the basis of the National Research University "Moscow Institute of Electronic Technology," students are trained in the direction of training 40.05.01 "Legal support of national security." A special feature of this direction is the presence in the curriculum, in addition to the traditional disciplines of the legal cycle (criminal law, criminal procedure, civil law, civil procedure, criminalistics, etc.), technical disciplines: computer science and information technologies in professional activity, the basics of the Java language, object-oriented programming, hybrid modeling, management of software projects, networks and communications, databases, Internet programming, neural networks, interactive graphical systems and many others. Legal disciplines make up 60 percent of the curriculum, 
and technical disciplines -40 percent. The training is carried out by experienced specialists who have scientific degrees of candidates and doctors of sciences.

Of course, there is no need for a large number of such specialized programs, since not all educational institutions have such a powerful technological and personnel base as MIET. Nevertheless, the need to provide for separate disciplines and (or) modules in disciplines that reflect the technological components of individual areas of professional training, in our opinion, should be implemented. Such a need should also be provided for the formation of knowledge about the peculiarities of persons with disabilities among future specialists in their profession.

It is also necessary to develop (quantitatively and qualitatively) additional education programs. Students of these courses can be employees who, in connection with their work functions, need to have knowledge and skills of communicating with people with disabilities. Taking into account the close connection between technologies and the possibilities of overcoming barriers to communication with people with disabilities with their help, it is necessary to develop such programs of advanced training and professional retraining.

\section{Conclusion}

Thus, modern technologies in criminal proceedings are aimed at solving a two-pronged goal: first, promoting the realization of human rights and the legal status of participants in criminal proceedings from among persons with disabilities; second, contributing to solving the problems facing criminal proceedings.

Taking into account the fact that we live in the era of automation, digitalization and AI systems, it is necessary to accept this fact and implement the existing technical and other achievements for the benefit of humanity. Since more and more people in the world and in specific states, including Russia, as a result of various reasons cannot be active members of society, and have difficulties with the realization of their rights, it is necessary to expand the scope of the introduction of modern technologies that can resolve the existing problems. One of these areas in the Russian state is criminal proceedings. 
Although the widespread introduction of modern technologies and high-tech programs into the criminal process is impossible, first, because of the financial component of the implementation of this policy, and second, because of the difficulties with establishing the reliability of the information obtained with their help, nevertheless modern technologies should be established as a full-fledged institution of criminal procedure law and a section of criminal procedure legislation should be devoted to it. It should fix the features of the use of technologies to ensure the realization of the rights of persons with disabilities participating in criminal proceedings; it is necessary to legislate the concept and types of such technologies, the basis and procedure for their application, the evidentiary value, etc. questions; a unified concept of the state's criminal policy should be developed, taking into account current problems in criminal proceedings, including the use of technologies in it and the updating of the content of the institute of participants. In particular, as a special, separate category, it is necessary to single out persons with disabilities. In relation to them, additional procedural guarantees are to be established.

This set of measures will reflect a compensatory approach to ensuring the implementation of the rights of persons with disabilities participating in criminal proceedings.

\section{References}

1. Alisievich, E.S., (2012). Promotion and protection of the rights of vulnerable groups in international law. Moscow: The Peoples' Friendship University of Russia (In Russ.).

2. Al-Jaleeli, Y.A., (2019). Providing entertainment for people with visual disabilities on civil aviation using (Braille-Barcode-Listening) BBL. Academic Journal of Interdisciplinary Studies. V. 8. (4), pp. 7277, doi: 10.36941/ajis-2019-0039.

3. Andreeva, O.S. and Bochkova, V.A., (2020). Dynamics of indicators of needs for technical means of rehabilitation for disabled people from among the adult population of the Russian Federation. Medical and social problems of disability, 2, pp. 82-88 (In Russ., abstract in Eng.). 
4. Barinova, G.V., (2015). Disability as a social phenomenon of modern Russian society (socio-philosophical analysis): Abstract of the Dr. Sci. (Philosophy) Dissertaion. Moscow.

5. Bertovsky, L.V., (2021). Legal regulation of criminal proceedings against minors as an element of criminal law and criminal procedure policy. Criminal policy in the field of ensuring the rights and legitimate interests of participants in criminal proceedings and the use of modern technologies: materials of All Russia (national) scientific and practical conference. Krasnoyarsk: Krasnoyarsk State Agrarian University, pp. $9-15$.

6. Bertovsky, L.V. and Devyatkin, G.S., (2019). Prospects for the use of blockchain technology in criminal court proceedings. In: Activity of law enforcement agencies in modern conditions. Collection of materials of the international scientific and practical conference. Irkutsk, pp. 116-118.

7. Brezhneva, A.D., (2017). The industry of computer games in the world economy. In: Innovative scientific research: theory, methodology, practice. Collection of articles of the VIII International Scientific and Practical Conference. Penza, pp. 129-133.

8. Davletov, A.A. and Azarenok, N.V., (2013). Purpose, purpose and tasks of criminal proceedings. News of higher educational institutions. Law studies, 1 (306), pp. 124-134.

9. Dokhoyan, A.M. and Maslova, I.A., (2020). Assistive technologies in inclusive education. Moscow: IPR Media.

10. Gudjonsson, G.H., et al., (2000). Assessing the capacity of people with intellectual disabilities to be witnesses in court. Psychological Medicine, 30(2), pp. 307-314, doi: 10.1017/So03329179900149X.

11. Ivanova, G.E., (2016). Medical rehabilitation in Russia. Prospects of development. Consillium Medicum, 18 (2.1), pp. 9-13.

12. Jones, M., et al., (2020). The digital health revolution and people with disabilities: perspective from the United States. International Journal of Environmental Research and Public Health, 17 (2), p. 381, doi: 10.3390/ijerph17020381.

13. Kachalov, V.I., (2017). Proceeding on the use of compulsory medical measures appointed by the court: issues of improvement. Russian justice, 4 (132), pp. 95-100. 
14. Kachalova, O.V., (2019). Can the health status of the accused affect the possibility of considering the case in a special order. Criminal process, 2 (170), p. 11.

15. Karpov, A.A., (2013). Assistive information technologies based on audiovisual speech interfaces. Proceedings of SPIIRAN, Issue 4 (27).

16. Kbar, G., et al., (2017). Unified interface for people with disabilities (UI-PWD) at smart city (design and implementation). In: Information Innovation Technology in Smart Cities, pp. 3-20, doi: 10.1007/978-981-10-1741-4_1.

17. Kurbatova, S.M., (2019). Formation of a cognitive approach to understanding a person with disabilities at the international legal level and its impact on national law (on the example of Russian criminal procedural legislation). Issues of Russian and International Law, $9(8-1)$.

18. Kurbatova, S.M., (2020). On the problems of participation of blind and visually impaired persons in criminal proceedings. Business. Education. Law, 2 (51), pp. 236-241.

19. Kurbatova, S.M., (2021a). Modern technologies as a means of realizing the rights and legitimate interests of participants in legal proceedings with limited opportunities. Military-legal and humanitarian sciences of Siberia, 2 (8), pp. 106-111.

20. Kurbatova, S.M., (2021b). Theoretical foundations of the criminal procedural status of persons with disabilities: problems of theory and practice. Krasnoyarsk: Krasnoyarsk State Agrarian University (In Russ).

21. Kurbatova, S.M., Aisner, L.Yu., and Naumkina, V.V., (2020). Accessible environment as a means of ensuring the rights of persons with disabilities and as a task of the modern social state. In: IOP Conference Series: Materials Science and Engineering. The conference proceedings ICCATS-2020. South Ural State University (national research university), Irkutsk National Research Technical University, Ural Federal University named after the first President of Russia B.N. Yeltsin, 032074, doi: 10.1088/1757-899X/962/3/032074.

22. Lewis, O., (2002). Protecting the rights of people with mental disabilities: the European convention on human rights. European Journal of Health Law, 9(4), pp. 293-320, doi: 10.1163/157180902100387044. 
23. Litvinova, E.S., (2011). Goals and essence of proof in the light of the question of the appointment of criminal proceedings. Problems of Law, 5 (31), pp. 201-204.

24. Maksimenko, Zh.A., et al., (2016). Technologies of virtual reality as a tool to create constructive behavioral scenarios in people with disabilities. Recent Trends in Science and Technology Management, 2, pp. 166-175.

25. Marzec, D. and Stefaniak, R., (2017). Providing equal opportunities for people with disabilities as a contemporary challenge. In: 4th International multidisciplinary scientific conference on social sciences and arts (SGEM). Conference proceedings. Sofia, pp. 463-470, doi: 10.5593/sgemsocial2017/34/S13.060.

26. Mikrina, V.G., (2019). International legal mechanisms for the protection of labor rights of the most vulnerable groups of the population: dissertation of the candidate of legal sciences. Moscow: Moscow State Institute of International Relations, pp. 12-13.

27. Nagornaya, L.A., (2021). Socialization of people with disabilities in the modern Russian society. In: European Proceedings of Social and Behavioural Sciences EpSBS, pp. 1138-1147, doi: 10.15405/ epsbs.2021.05.152.

28. Nesmeyanova, S.E. and Kalinina, E.G., (2017). The concept of vulnerability of individual groups of persons: international and national experience. Russian Law: Education, Practice, Science, 4, pp. 7-12.

29. Nikolyuk, V.V. and Kalnitsky, V.V., (1990). Criminal procedural activity on the use of compulsory medical measures. Omsk: Omsk Academy of the Ministry of Internal Affairs of Russia.

30. Oxley, T.J., et al. (2020). Motor neuroprosthesis implanted with neurointerventional surgery improves capacity for activities of daily living tasks in severe paralysis: first in-human experience [online], doi: 10.1136/neurintsurg-2020-016862. Available at: https://jnis.bmj. com/content/early/2020/10/30/neurintsurg-2020-016862 [Accessed 25.07.2021].

31. Parmar, H., Nutter, B., Long, R., Antani, S., and Mitra, S., (2020). Spatiotemporal feature extraction and classification of Alzheimer's 
disease using deep learning 3D-CNN for fMRI data. Journal of Medical Imaging, 7 (05), doi: 10.1117/1.JMI.7.5.056001.

32. Plotnikova, A.M., (2019). Names of socially unprotected groups of persons in the legal space and beyond. Izvestiya UrFU. Ser. 2. Humanities. Vol. 21, 4 (193), pp. 209-218.

33. Polutin, S.V., Nikishin, M.B., Zakhryapin, A.V., and Mukhametzyanova, A.R., (2005). Application of network and virtual technologies in solving problems of rehabilitation and distance education of people with disabilities. Integration of education, 1/2, pp. 97-101.

34. Poveda Zavala, S., et al. (2019). Brain computer interface application for people with movement disabilities. Lecture Notes in Computer Science. T. 11354 LNCS, pp. 35-47, doi: 10.1007/978-3030-15127-0_4.

35. Puzin, S.N., Gridin, L.A., and Dmitrieva, N.V., (2017). To the history of medical rehabilitation in Russia. History of medicine. Vol. 4, 2, pp. 125-135.

36. Ryazantsev, V.M., Lazareva, O.V., and Volkova, Yu.V., (2020). Changes in providing disabled people with technical means of rehabilitation. In: Collection of materials of the scientific and practical conference on topical problems of medical and social expertise. Moscow, pp. 27-29.

37. Schmetzke, A., (2002). Accessibility of web-based information resources for people with disabilities. Library Hi Tech. 21 (2), pp. 135136.

38. Sedykh, I.A., (2020). The industry of computer games. Higher School of Economics, Development Center. Moscow.

39. Shabalina, O., et al., (2018). A mobile game for training shopping skills for people with intellectual disabilities. In: Proceedings of the 12th European Conference on Game-Based Learning, ECGBL 2018. ISBN (Electronic) 9781911218999. Pp. 565-573.

40. Shatalov, A.S., (2014). Ensuring the rights and legitimate interests of minors in criminal proceedings. Bulletin of the Institute: crime, punishment, correction, 2 (26), pp. 41-45.

41. Shatalov, A.S., (2020). The use of modern information technologies in criminal proceedings in a criminal case. In: Criminal proceeding of Russia: problems and prospects of development. Collection 
of materials of the All-Russian scientific and practical Conference. Moscow: Inter-municipal Department of the Ministry of Internal Affairs of the Russian Federation, pp. 239-244.

42. Shatalov, A.S., (2021). On the need to allocate persons with disabilities to a separate group of participants in criminal proceedings. In: Ensuring the rights of participants in criminal proceedings with disabilities: a compensatory approach. Materials of the International Scientific and Practical Conference. Krasnoyarsk: Publishing House of the Krasnoyarsk State Agrarian University, pp. 200-207.

43. Sinkovskaya, I.G., et al. (2020). Vitality as an indicator of the life quality of people with disabilities. In: European Proceedings of Social and Behavioural Sciences EpSBS. Krasnoyarsk Science and Technology City Hall. Krasnoyarsk, pp. 809-817, doi: 10.15405/epsbs.2020.10.03.95.

44. Vorotnikova, Yu.S., Gavrilov, K.A., Drobysheva, E.E., et al., in Chernov, S.S., (2010). Humanitarian problems of modernity: man and society. Novosibirsk: Center for the Development of Scientific Cooperation, book 13.

45. Voskobitova, L.A., (2019). Fundamentals of criminal justice and digitalization. In: The Russian legal system in the conditions of the Fourth Industrial Revolution: materials of the VI Moscow Legal Forum of the XVI International Scientific and Practical Conference. Moscow: Prospekt, pp. 75-86.

46. Zelenina, O.A., (2010). The essence of the category "participant of criminal proceedings" in the science of criminal procedural law. Society and law, 4 (31), pp. 238-245.

\section{Information about the Authors}

Svetlana M. Kurbatova, Cand. Sci. (Law), Associate Professor, Krasnoyarsk State Agrarian University, Krasnoyarsk, Russia

90 ulitsa Mira, Krasnoyarsk 660049, Russia

sveta_kurbatova@mail.ru

ORCID: 0000-0001-8518-9233

Larisa Yu. Aisner, Cand. Sci. (Cultural Studies), Associate Professor, Krasnoyarsk State Agrarian University, Krasnoyarsk, Russia

90 ulitsa Mira, Krasnoyarsk 660049, Russia

larisa-ajsner@yandex.ru

ORCID: 0000-0002-7093-4162 